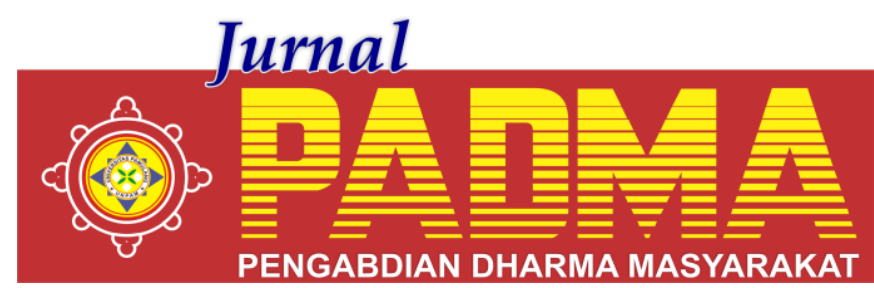

VOLUME 1, NOMOR 3, JULI 2021

\title{
PELATIHAN KEMAMPUAN KOMUNIKASI BAGI PEMUDA PADA KARANG TARUNA KELURAHAN KEDAUNG
}

\author{
${ }^{1 *}$ Nurul Ilham, ${ }^{2}$ Roni Fadli, ${ }^{3}$ Anggada Bayu Seta, ${ }^{4}$ Sri Mulyani, ${ }^{5}$ Siti Nurcahayati \\ Universitas Pamulang, Tangerang Selatan, Banten, Indonesia \\ *dosen02548@unpam.ac.id
}

\begin{abstract}
Abstrak
Kegiatan pengabdian kepada masyarakat diselenggaran dengan tujuan untuk memberikan pemahaman komunikasi yang baik sesuai dengan tujuan yang di harapkan hal ini dapat diketahui dari seringkali terjadi bias komunikasi yang tercipta diantara para anggota organisasi dalam menafsirkan pesan yang diterima dan dikirimkan oleh sesama anggota organisasi, selanjutnya yang juga patut mendapat perhatian terkait dengan komunikasi adalah bentuk penyampaian informasi yang kurang jelas dimana hal ini seringkali menciptakan multitafsir diantara para anggota organisasi karang taruna kelurahan kedaung dalam memfilter dan menafsirkan pesan yang diberikan kepada mereka. Hal lain yang juga menarik untuk mendapat perhatian terkait dengan komunikasi adalah terbatasnya akses dan media dalam memperlancar aliran komunikasi yang dapat di pergunakan oleh seluruh anggota organisasi karang taruna kelurahan kedaung dalam memperoleh dan mengirimkan pesan kepada anggota organisasi yang lain .
\end{abstract}

Kata Kunci: Pelatihan, Komunikasi, Karang Taruna

\section{Abstract}

Community service activities are held with the aim of providing a good understanding of communication in accordance with the expected goals. This can be seen from the frequent occurrence of communication bias created among members of the organization in interpreting messages received and sent by fellow members of the organization. Getting attention related to communication is a form of conveying information that is not clear where this often creates multiple interpretations among members of the Kedaung Village Youth Organization in filtering and interpreting the messages given to them. Another thing that is also interesting to get attention related to communication is the limited access and media in facilitating the flow of communication that can be used by all members of the Kedaung village youth organization in obtaining and sending messages to other members of the organization.

Keywords: Training, Communication, Youth organization

\section{PENDAHULUAN}

Manusia sebagai makhluk sosial artinya manusia membutuhkan orang lain dan lingkungan sosialnya sebagai wadah untuk bersosialisasi. Bersosialisasi disini berarti menjadi lingkungan sosial sebagai salah satu habitatnya, yang berati tiap manusia saling membutuhkan satu sama lainnya untuk bersosialisasi dan berinteraksi. Manusia pun berlaku sebagai makhluk sosial yang saling berhubungan dan keterkaitannya dengan lingkungan dan tempat tinggalnya. Manusia bersikap sosial dengan cara memanfaatkan alam dan lingkungan untuk menyempurnakan serta meningkatkan kesejahteraan hidupnya demi kelangsungan hidup sejenisnya. Namun potensi yang ada dalam diri manusia itu hanya mungkin berkembang bila ia hidup dan belajar di tengah-tengah manusia. Untuk bisa berjalan saja manusia harus belajar dari manusia lainnya. "Organisasi merupakan tata hubungan sosial, dimana setiap individu yang melakukan kerjasama melakukan proses interaksi dengan individu lainnya". Weber dalam Silalahi, (2011:124). Berdasarkan pengertian tersebut dapat disimpullkan bahwa hubungan sosial setiap individu sangat penting untuk terjadinya proses kerjasama yang baik sehingga tata hubungan sosial antar individu sesuai dengan tujuan yang akan dicapai oleh organisasi. 
Salah satu organisasi yang dimaksud adalah Karang Taruna Kelurahan Kedaung, dimana di dalamnya terdapat elemen yang sangat sentral yaitu pemuda. Karena pemuda adalah seseorang yang mempunyai jiwa semangat yang tinggi dalam hal pengembangan diri maupun komunitasnya. Sehingga pemuda merupakan sumber daya manusia pembangunan baik saat ini maupun masa datang. Sebagai calon generasi penerus yang akan menggantikan generasi sebelumnya. Pemuda merupakan penerus perjuangan generasi terdahulu untuk mewujukan cita-cita bangsa. Pemuda menjadi harapan dalam setiap kemajuan di dalam suatu bangsa, Pemuda lah yang dapat merubah pandangan orang terhadap suatu bangsa dan menjadi tumpuan para generasi terdahulu untuk mengembangkan suatu bangsa dengan ide-ide ataupun gagasan yang berilmu, wawasan yang luas, serta berdasarkan kepada nilai-nilai dan norma yang berlaku di dalam masyarakat.

Karang Taruna adalah Organisasi Sosial wadah pengembangan generasi muda yang tumbuh dan berkembang atas dasar kesadaran dan tanggung jawab sosial dari, oleh dan untuk masyarakat terutama generasi muda di wilayah desa/ kelurahan dan terutama bergerak di bidang usaha kesejahteraan sosial. Karang Taruna adalah suatu organisasi sosial, perkumpulan sosial yang dibentuk oleh masyarakat yang berfungsi sebagai sarana partisipasi masyarakat dalam melaksanakan Usaha Kesejahteraan Sosial (UKS). Sebagai wadah pengembangan generasi muda, Karang Taruna merupakan tempat diselenggarakannya berbagai upaya atau kegiatan untuk meningkatkan dan mengembangkan cipta, rasa, karsa, dan karya generasi muda dalam rangka pengembangan sumber daya manusia (SDM).

Karang Taruna tumbuh dan berkembang atas dasar adanya kesadaran terhadap keadaan dan permasalahan di lingkungannya serta adanya tanggung jawab sosial untuk turut berusaha menanganinya. Kesadaran dan tanggung jawab sosial tersebut merupakan modal dasar tumbuh dan berkembangnya Karang Taruna. Karang Taruna tumbuh dan berkembang dari generasi muda, diurus atau dikelola oleh generasi muda dan untuk kepentingan generasi muda dan masyarakat di wilayah desa/kelurahan atau komunitas adat sederajat. Karenanya setiap desa/kelurahan atau komunitas adat sederajat dapat menumbuhkan dan mengembangkan Karang Tarunanya sendiri. Gerakannya di bidang Usaha Kesejahteraan Sosial berarti bahwa semua upaya program dan kegiatan yang diselenggarakan Karang Taruna ditujukan guna mewujudkan kesejahteraan sosial masyarakat terutama generasi mudanya.

Pengurus Karang Taruna tingkat Desa/Kelurahan dipilih dan disahkan dalam Temu Karya Desa/Kelurahan. Pengurus Karang Taruna tingkat Desa/Kelurahan dikukuhkan dengan Surat Keputusan Kepala Desa/Lurah dan dilantik oleh Kepala Desa/Lurah setempat. Pengurus Karang Taruna tingkat Desa/Kelurahan selanjutnya berfungsi sebagai Pelaksana Organisasi dalam diwilayahnya. Karang Taruna tingkat Desa/Kelurahan atau komunitas sosial yang sederajat memiliki Pengurus minimal 35 Orang.

Kelangsungan organisasi dalam hal ini Karang Taruna Kelurahan Kedaung dapat di tentukan dengan memperhatikan berbagai kepentingan dan kebutuhan orang yang ada dalam organisasi. Kohesi kelompok yang dikemukakan di atas merupakan bagian dari upaya untuk mengetahui keinginan kelompok tersebut. Hubungan yang harmonis antara anggota dengan organisasi secara signifikan akan mempengaruhi kinerja organi-sasi, dan jika kinerja ini berhasil sesuai dengan rencana, maka produktivitas organisasi juga akan meningkat. Produktivitas yang meningkat merupakan indikator bahwa suatu organisasi mampu mengkomunikasikan rencananya kepada seluruh jajaran organisasi, sekaligus mampu mengkomunikasikan peran organisasi tersebut di lingkungannya.

\section{METODE}

Metode pendekatan yang digunakan dalam kegiatan pengabdian kepada masyarakat ini adalah:

1. Penyuluhan

Penyuluhan adalah usaha memberikan keterangan, penjelasan, petunjuk, bimbingan, tuntunan, jalan, dan arah yang harus ditempuh oleh setiap 
orang sehingga dapat memecahkan masalah yang dihadapinya dan meningkatkan kualitas hidupnya. Kegiatan penyuluhan ini bertujuan untuk untuk meningkatkan kemampuan komunikasi dan keterbukaan diantara seluruh anggota karang taruna kelurahan kedaung dengan didasari oleh keterbukaan, rasa saling menghargai, membutuhkan, serta beragam nilai-nilai positif lainnya yang bertujuan untuk menjaga dan meningkatkan solidaritas, produktivitas dan efektivitas kerja. Para pemuda didalam lingkup organisasi karang taruna kelurahan kedaung.

\section{Pelatihan}

Menurut Widodo (2015:82), "Pelatihan merupakan serangkaian aktivitas individu dalam meningkatkan keahlian dan pengetahuan secara sistematis sehingga mampu memiliki kinerja yang profesional dibidangnya, pelatihan juga sebagai proses pembelajaran yang memungkinkan pegawai melaksanakan pekerjaan yang sekarang sesuai dengan standar". Pada kegiatan pengabdian masyarakat yang akan dilaksanakan di Karang Taruna Kelurahan Kedaung adalah terkait dengan cara peningkatan kemampuan berkomunikasi yang efektif dan efisien didalam lingkup organisasi karang taruna kelurahan kedaung, pelatihan yang akan dilakukan terkait cara penyampaian proses komunikasi yang dimulai dari sumber informasi atau pengirim pesan, dilanjutkan dengan penggunaan transmisi atau alat pengirim pesan, sampai dengan pesan atau informasi tersebut sampai kepada penerima pesan sebagai tujuan akhir dari proses penyampaian informasi secara utuh sebagai bentuk terjadinya komunikasi yang efektif dan efisien bagi seluruh anggota organisasi karang taruna kelurahan kedaung.

\section{HASIL DAN PEMBAHASAN}

Berdasarkan hasil observasi yang telah dilakukan, dapat di ketahui dan pahami bahwa organisasi karang taruna kelurahan kedaung dalam menjalankan aktivitas organisasinya, tidak luput dari adanya masalah-masalah internal didalam tubuh organisasi karang taruna yang menyebabkan koordinasi dan efektivitas tugas kerja tidaklah berjaan dengan baik.

Beberapa fakta yang ditemukan terkait dengan komunikasi yang ada didalam organisasi karang taruna kelurahan kedaung antara lain , bahwa organisasi karang taruna kelurahan kedaung masih belum berjalan dengan baik sesuai dengan tujuan yang di harapkan hal ini dapat diketahui dari seringkali terjadi bias komunikasi yang tercipta diantara para anggota organisasi dalam menafsirkan pesan yang diterima dan dikirimkan oleh sesama anggota organisasi, selanjutnya yang juga patut mendapat perhatian terkait dengan komunikasi adalah bentuk penyampaian informasi yang kurang jelas dimana hal ini seringkali menciptakan multitafsir diantara para anggota organisasi karang taruna kelurahan kedaung dalam memfilter dan menafsirkan pesan yang diberikan kepada mereka. Hal lain yang juga menarik untuk mendapat perhatian terkait dengan komunikasi adalah terbatasnya akses dan media dalam memperlancar aliran komunikasi yang dapat di pergunakan oleh seluruh anggota organisasi karang taruna kelurahan kedaung dalam memperoleh dan mengirimkan pesan kepada anggota organisasi yang lain .

Serta perbedaan reaksi emosional seseorang mungkin bereaksi secara berbeda terhadap kata yang sama pada keadaan yang berbeda. Suatu pesan yang jelas dapat diterima di suatu kondisi akan dapat membingungkan dalam situasi yang berbeda. Hal ini tergantung pada hubungan emosional antara penerima dengan pengirim pesan. Setiap pesan paling tidak mengandung dua hal yaitu dalam artian isi yang berkaitan dengan subjek suatu pesan dan dalam artian hubungan yang memberikan sifat suatu interaksi antara pengirim dan penerima pesan. Ini terjadi pada anggota organisasi karang taruna.

Beberapa permasalahan yang telah dipaparkan oleh penulis terkait dengan komunikasi yang timbul dan terjadi didalam internal bahwa organisasi karang taruna kelurahan kedaung diatas jika dibiarkan akan membawa dampak buruk bagi kelangsungan organisasi. Untuk itu, diperlukan sebuah penyuluhan dan pelatihan tentang pengetahuan dalam berkomunikasi 
mengenai tata cara komunikasi baik dan efektif sangatlah penting untuk dimiliki oleh tiap elemen yang ada didalam organisasi kepemudaan tersebut.

\section{PENUTUP \\ KESIMPULAN DAN SARAN}

Biasnya komunikasi yang terjadi diantara para anggota organisasi karang taruna kelurahan kedaung disebabkan oleh perbedaan latar belakang usia, latar belakang pendidikan dan latar belakang budaya yang berbeda - beda dari setiap individu angota organisasi Karang taruna kelurahan kedaung sehingga sering kali menimbulkan persepsi yang salah pada proses penyampaian informasi dari sumber informasi atau pemberi informasi kepada penerima informasi, bias komunikasi ini cukup sering terjadi dan mempunyai akibat negative yang cukup besar bagi komunikasi diantara anggota organisasi.

Selain itu penyampaian komunikasi yang kurang jelas juga sering terjadi diantara para anggota organisasi karang taruna kelurahan kedaung baik itu penyampaian informasi dalam bentuk komunikasi kebawah, komunikasi ke atas, maupun komunikasi sejajar maupun horizontal. Permasalahan yang timbul disebabkan terbatasnya akses dan media dalam memperoleh informasi juga menjadi kendala yang dialami oleh beberapa anggota organisasi karang taruna kelurahan kedaung sehinggga menyebabkan sebagian anggota organisasi mendapatkan informasi yang serupa atau sejenis lebih dari sekali namun disisi lain terdapat anggota organisasi lain yang belum mendapatkan informasi tersebut Lebih lanjut, kami selaku tim pengabdian masyarakat akan membantu memecahkan masalah yang dihadapi oleh Karang taruna kelurahan kedaung dengan pemberian penyuluhan dan pelatihan kemampuan komunikasi untuk seluruh anggota organisasi pemuda yang tergabung didalam karang taruna kelurahan kedaung.

\section{DAFTAR PUSTAKA}

Ulber, Silalahi. 2011. Asas Asas Manajemen. Bandung: Refika Aditama

Eko, Widodo Suparno. 2015. Manajemen Pengembangan Sumber Daya Manusia.Yogyakarta: Pustaka Pelajar

Fadli, R. (2019). Pengaruh Kepemimpinan Terhadap Kinerja Karyawan PT. Tunas Perkasa Tekindo. Jurnal Semarak: Jurnal Ilmiah Prodi Manajemen Universitas Pamulang, 2 (2), 85-100.

Fadli, R. (2020). Pelatihan Manajemen Waktu dalam Mewujudkan Produktivitas Kerja pada Tenaga Kesehatan RSU Bhakti Asih, Jurnal Baktimas, 2 (2), 100-103.

Haque, MG., Munawaroh, Sunarsi, D., (2020). Analysis of SMEs Culinary Marketing Strategy During Covid 19 Pancemic: A Study at "Sate Bebek Cilegon" Resto in Cilegon, Banten. International Journal of Education, Information Technology, and Others. Vol.3. Issue 2.

Mulyani, S. (2020). Mengelola Konflik Dalam Organisasi Untuk Menunjang Efektivitas Kerja Karyawan CV. Enigma, Jurnal Pengabdian Dharma Laksana, 2 (2), 92-96. 